\title{
Challenges to regional universities in Russia: The case of Ural Federal Okrug
}

\author{
Marina Vidrevich", and Irina Pervukhina \\ Ural State University, 8 Marta/NarodnoyVoli Str., 620144, Ekaterinburg, Russia
}

\begin{abstract}
The paper aims to analyze the state of the higher education system in Russia and its role in the regional development. It also provides some recommendations on how to modernize universities, modify their functions and eventually integrate universities into the regional economy in order to lay down the foundation for a quantum leap in the implementation of the National Education Project at the regional level.It is shown that the way out might be creation of well-functioning co-ordinating bodies at the regional level that comprise the key regional actors including private sector and that take a long-term wider view of regional development, not just focusing on economic but also social, cultural and environmental development.
\end{abstract}

\section{Introduction}

The well-being of a society is largely determined by its capability to offer goods and services, as well as institutions and mechanisms for their development which satisfy consumers' needs and expectations and meet international standards. As countries are turning their production towards value-added segments and knowledge-intensive products and services, there is greater dependency on access to new technologies, knowledge and skills. Universities play several roles in their communities and one of their key functions is to support and drive regional, social and community development. With the parallel processes of globalisation and localisation, the local availability of knowledge and skills is becoming increasingly important. To score highly, universities should be active players, linked to their external environment by having a strong presence in the community [1].

Economic and socio-cultural uncertainty caused by the high dynamics of economic and social processes generates global risks at the macro level. The responses (both explicit and latent) to these challenges have occurred in the emergence of the Third Generation University with new goals and objectives [2,3]. According to Wissema [3] in this phase, universities not only create professionals (first generation universities), professionals and scientists (second generation universities), but professionals, scientists andentrepreneursat the same time (third generation universities). This is where not only education and research aresignificant but the utilization of knowledge created in universities is also crucial. Thus, third generation universities are expected to contribute to the enhancement of the competitiveness of a regionthroughthe enhancement of the competitiveness of enterprises [4].Universities are becoming subject to fundamental change, evolving from science-based,

*Corresponding author: mbv@usue.ru 
monodisciplinary institutions into transfunctional, economic entities, which beyond student training and publicationsare engaged in the production of revenues from its commercial activities such as technologyand 'know how' knowledge transfer [5].

The paper aims to analyze the state of the tertiary sector in Russia and its role in the regional development.It also provides some recommendations on how to modernize universities, modify their functions and eventually integrate universities into the regional economy in order to lay down the foundation for a quantum leap in the implementation of the National Education Project at the regional level.

\section{Trends in the development of higher education in Russia}

Today Russia's higher education not only follows the global trends but considers local availability of knowledge and skills as an increasingly important factor.

The following trends underlie the development of higher education in Russia [6]:

- integration into the global educational space;

- complexity and inconsistency of embracing best educational practices in the country's tertiary sector;

- the threat to the national identity of higher education;

- regionalization of the Russian tertiary sector;

- uncertainty caused by the perspectives of further development of higher education.

Experts' opinions are polar: from the forecast of a 'bright future' to statements about the 'death' of the university as a higher education institution.

The Russian Federal government pursues the policy of providing priority support to a small group of universities which is made up of 10 federal universities, 29 national research universities, 11 flagship universities and about 20 other universities. This policy has led to the fact that the national and regional higher education systems are going through a bad stretch. The majority of provincial universities are facing financial, organizational and human resources challenges. Many demonstrate inefficiency and are on the verge of closure. Some come under threat of losing their independent status and being restructured as branches, or taken over by other educational organizations. This trend is most apparent in regional centres and towns (there are approximately 60 of them) where the university is the major employer. The closure or loss of control over a higher education institution (HEI) leads to an outflow of young people and intellectual capital, loss of prospects for sustainable development, attractiveness, and innovative potential of a region. As a result, prerequisites are created for the development of negative social, socio-economic and socio-cultural trends in a region. The main challenge regional universities are facing nowadays is the lack of resources for development, including limited financial, legal and organizational resources of regional authorities and the disunity of universities within the region. The problem can be solved by attracting private investment and building regional or/and macroregional networks of universities.

\section{Interuniversity networking on the regional level}

The Third Generation University should be an innovative and entrepreneurial structure that is actively involved in the life of society through knowledge transfer to human capital, intellectual property, innovative enterprises, industry, political institutions, etc. This structure may ensure continuous learning and technology transfer, beneficial to local authorities and regional business $[7,8]$. For most Russian regional universities, facing financial and social difficulties, this is the only opportunity to stay afloat and develop successfully. Close connection with the local community is not only the key to survival, but also a chance to 
tailor education to the realities of modern life, to improve the quality of teaching, to strengthen its practical orientation. International experience convincingly demonstrates how thoughtful and active interaction of the university with the local community can change the existence of the university and its perceived status in society.

The creation and development of regional university networks is a prerequisite for their existence at a time of social and economic uncertainty. Inter-university networks are defined as formal, multilateral, multi-purpose and voluntary cooperative arrangements between HEIs [9, p. 7]. It is a system of relationshipsbetween HEIs in the common space-and-time educational continuum that is influenced by mechanisms of implementing innovative projects targeting the content of teaching and learning, management and academic research [10]. This kind of interaction would exert a synergistic effect and significantly increase the resource capacity and efficiency of each partner.

The existing types of inter-university cooperation at the regional level are linear in nature. However, there is a pressing need for new forms and methods of inter-university collaboration that would be able to respond to the challenges of the Russian higher education system. On the one hand, these forms are expected to enhance the development prospects for each member; on the other hand, they would act as a driving force for the development of a regional higher education system and a region as a whole. A new form of inter-university collaboration may evolve as non-linear networking.

Inter-university networks are characterized by:

- the principles of openness, responsibility, trust, mutual interest; at the same time all member institutions retain their separate autonomy and identity [9];

- close connection between higher education, social institutions and new social practices;

- complexity of organizational processes and inter-institutional relations, due to a large number of partners engaged in inter-university networks and diverse areas of cooperation (e.g., education, science, culture);

- cooperation initiated by university management and academic staff via the existing informal contacts;

- complex time scope of network projects: cooperation may start long before the formal consolidation of contracts;

- the need to remain an on-going relevance and the capacity to change and adapt to new trends and shifting needs [11];

- integration and provision of resources (including financial and human resources);

- an ability to encourage and use innovations.

The adoption of a non-linear model of higher education development will help regions gain a competitive advantage in the global educational space, enhance the role of higher education in society, and turn it into a driver of region's social, economic and cultural development.

To illustrate the statement, we will analyze the state of higher education in Ural Federal Okrug (UFO) that includes Kurganskaya, Sverdlovskaya, Tyumenskaya, and Chelyabinskaya Oblasts;Khanty-Mansi Autonomous Okrug (KHMAO) and Yamalo-Nenets Autonomous Okrug (YANAO).

There are 102 HEIs (universities) located in UFO, among them are 45 state, 15 non-state and 42 branches of regional and national universities (Table 1). Six state universities of UFO are included in the RAEX-100 Rating of Russian universities (Table 2). 
Table 1. Universities in Ural Federal Okrug (2020)

\begin{tabular}{|c|c|c|c|c|}
\hline Region & Total & State universities & $\begin{array}{c}\text { Non-state } \\
\text { universities }\end{array}$ & Branches \\
\hline $\begin{array}{c}\text { Kurganskaya } \\
\text { Oblast }\end{array}$ & 8 & 4 & - & 4 \\
\hline $\begin{array}{c}\text { Sverdlovskaya } \\
\text { Oblast }\end{array}$ & 44 & 18 & 12 & 14 \\
\hline $\begin{array}{c}\text { Tyumenskaya } \\
\text { Oblast }\end{array}$ & 10 & 7 & - & 3 \\
\hline $\begin{array}{c}\text { Chalybinskaya } \\
\text { Oblast }\end{array}$ & 28 & 11 & - & 14 \\
\hline KHMAO & 6 & 5 & - & 6 \\
\hline YANAO & 6 & & - & 3 \\
\hline
\end{tabular}

Source: https://kurganobl.ru/spisok-obrazovatelnyh-organizaciy-vysshego-obrazovaniya-kurganskoyoblastihttps://vuz.edunetwork.ru/

Table 2. UFO universities included in the RAEX-100 Rating (2020)

\begin{tabular}{|c|c|c|c|}
\hline University & $\begin{array}{c}\text { RAEX-100 } \\
\text { Rating }\end{array}$ & $\begin{array}{c}\text { Functionality } \\
\text { Rating }\end{array}$ & Region \\
\hline Ural Federal University & 12 & 4.0418 & \multirow{2}{*}{ Sverdlovskaya Oblast } \\
\hline $\begin{array}{c}\text { Ural State Medical } \\
\text { University }\end{array}$ & 89 & 1.9081 & \\
\hline $\begin{array}{c}\text { Industrial University of } \\
\text { Tyumen }\end{array}$ & 71 & 2.0863 & \multirow{3}{*}{ Tyumenskaya Oblast } \\
\hline Tyumen State University & 66 & 2.1054 & \\
\hline $\begin{array}{c}\text { Tyumen State Medical } \\
\text { University }\end{array}$ & 90 & 1.8992 & \\
\hline $\begin{array}{l}\text { South Ural State } \\
\text { University }\end{array}$ & 58 & 2.2960 & Chalybinskaya Oblast \\
\hline
\end{tabular}

Source: https://raex-rr.com/education/universities/rating of universities of russia

In terms of student admission and the Unified National Exam (UNE) average grade, UFO universities, primarily universities in Sverdlovskaya Oblast, rank No 4 (state-subsidized students) and No 8 (fee-paying students) among the 2020 Top-10 regions (Table 3), which means that they are 'magnet' universitiesfor local as well as other regions' school leavers. In future these graduates will enter the local labour market and contribute to a region's human capital base [12].

Table 3.The Unified National Exam average grade in the top 10 regions of the Russian Federation (2020)

\begin{tabular}{|c|c|c|c|c|}
\hline \multirow{2}{*}{ Rank } & \multicolumn{2}{|c|}{ State-subsidized studies } & \multicolumn{2}{c|}{ Fee-paying studies } \\
\cline { 2 - 5 } & Region & $\begin{array}{c}\text { UNE } \\
\text { average } \\
\text { grade }\end{array}$ & Region & $\begin{array}{c}\text { UNE } \\
\text { average } \\
\text { grade }\end{array}$ \\
\hline 1. & $\begin{array}{c}\text { Moscow and Moskovskaya } \\
\text { Oblast }\end{array}$ & 80.3 & Moscow and Moskovskaya & 69.3 \\
\hline 2. & St. Petersburg & 79.5 & $\begin{array}{c}\text { St. Petersburg and } \\
\text { Leningradskaya Oblast }\end{array}$ & 68.6 \\
\hline 3. & Tomskaya Oblast & 73.7 & Republic of Tatarstan & 66.9
\end{tabular}


Continuation of table 3

\begin{tabular}{|c|c|c|c|c|}
\multirow{2}{*}{ Rank } & \multicolumn{2}{|c|}{ State-subsidized studies } & \multicolumn{2}{c|}{ Fee-paying studies } \\
\cline { 2 - 5 } & Region & $\begin{array}{c}\text { UNE } \\
\text { average } \\
\text { grade }\end{array}$ & Region & $\begin{array}{c}\text { UNE } \\
\text { average } \\
\text { grade }\end{array}$ \\
\hline 4. & Sverdlovskaya Oblast & 73.5 & Kaliningradskaya Oblast & 66.2 \\
\hline 5. & Republic of Tatarstan & 73.3 & Nizhny Novgorod Oblast & 65.6 \\
\hline 6. & Novosibirskaya Oblast & 72.1 & Tomskaya Oblast & 65.1 \\
\hline 7. & Krasnodar Krai & 71.0 & Krasnodar Krai & 64.7 \\
\hline 8. & Kaliningradskaya Oblast & 71.6 & Sverdlovskaya Oblast & 64.1 \\
\hline 9. & Yaroslavskaya Oblast & 71.7 & Bashkortostan Republic & 64.0 \\
\hline 10. & Kaluga Oblast & 71.0 & PermskiyKrai & 64.5 \\
\hline
\end{tabular}

Source:https://ege.hse.ru/stata 2020

However, despite its high research and educational potential, regional higher education systems are in many instances ill-suited to further development of a territory. One of the issues is to train specialists with skills needed in the domestic and international labour markets, with enhanced capacity for technological innovation. There is a need to acknowledge that the regional tertiary sector should be seen as a laboratory for innovative research projects and a source of financial resources to enhance the global competitiveness of the institution.HEIs have long seen service to the community as part of their role, yet this function is often underdeveloped. In regional development much depends on effective partnerships based on shared interests of HEIs with academic and sectorial science, private business, and the global educational system.

The strategic goal of developing regional HEIs is to engage them in several dimensions notably: knowledge creation through research and technology transfer; knowledge transfer through education and human resources development and cultural and community development, which can, among other things, create the conditions in which innovation thrives. The responses to this challenge can vary from region to region. For example, the Urals Research, Educational and Innovation Center (UREIC) is a formal cooperative arrangement between the leading UFO universities, with the Ural Federal University as a coordinating institution of the partnership. The member institutions determine the structure of the network, define the roles of each actor, prescribe the issues which are discussed and how they are dealt with and set the decision rules [13]

The creation of the UREIC will help to tackle three categories of tasks the regional university community is facing with, notably:

1) educational tasks: improved quality of education; strengthened students' employability; modern curriculum building;

2) research tasks: increased joint research; increased intellectual capacity of academics; increased access to funding opportunities; increased research cooperation with business and industry; 
3) organizational tasks: capacity building of administrative staff; enhanced reputation and visibility of universities; improved organization and management within the university; enhanced regional socio-economic environment of universities.

\section{Conclusion}

Universities have different roles regarding the enhancement of competitiveness in regionswith different competitive potential. The stronger the competitive potential of the region, thestronger third generation university functions are expected to be present. In contrast, in regions with relatively low competitive potential the presence of second generation university functions is sufficient [4].

In a context of globalisation, HEIs are observed to increasingly cooperate in international, domestic and regional inter-university networks. These networks promise favourable benefits, such as increased institutional competitiveness, access to larger academic environments, greater global visibility, improved service to students and extended organisational capacities.

A crucial step is to create well-functioning co-ordinating bodies at the regional level that comprise the key regional actors including private sector and that take a long-term wider view of regional development, not just focusing on economic but also social, cultural and environmental development. HEIs can play a key role in joining up a wide range of national policies at the regional level. These policies include science and technology, industry,education and skills, health, culture and sport, environmental sustainability and social inclusion.

\section{References}

1. A Guiding Framework for Entrepreneurial Universities. (OECD, 2012). URL: https://www.oecd.org/site/cfecpr/EC-

OECD\%20Entrepreneurial\%20Universities\%20Framework.pdf

2. A.S. Kisljakov, A.D. Ishhenko. Vlast [Power], 27 (6). 196 (2019). [In Russian]. DOI: https://doi.org/10.31171/vlast.v27i6.6850

3. J. G. Wissema, Towards the Third Generation University: Managing the University in Transition(Edward Elgar, 2009)

4. M. Lukovics, B. Zuti. SSRN (September 4, 2017). URL: https://ssrn.com/abstract $=3022717$ or http://dx.doi.org/10.2139/ssrn.3022717

5. M.B. Vidrevich, I.V. Pervukhina. Advances in Social Science, Education and Humanities Research, 240, 680 (2018

6. G.E. Zborovsky, P.A. Ambarova. Integracija obrazovanija [Integration of Education]. 21 (3). 405 (2017). [In Russian]. DOI :http://dx.doi.org/10.15507/19919468.088.021.201703.405-420

7. T.A. Balmasova. High. Educ. Rus., 8-9. 48 (2016) [In Russian]. URL :https://cyberleninka.ru/article/n/tretya-missiya-universiteta-novyy-vektorrazvitiya/viewer

8. M. D. Schelkunov. Vestnik jekonomiki, prava i sociologii [Bulletin of Economics, Law and Sociology], 1. 187-192 (2017) [In Russian]. URL : https://cyberleninka.ru/article/n/universitety-novogo-pokoleniya

9. M.C. Fastner. Inter-university Networks: Rhetorics vs. Reality Objectives and Activities of Members of the European Consortium of Innovative Universities (Master's Thesis, 2016). URL: https://essay.utwente.nl/view/domain/89.type.html 
10. G.E. Zborovsky, E.A. Shuklina, P.A. Ambarova. High, Educ. Rus., 12. 34 (2016). [In Russian]. URL: https://science.urfu.ru/ru/publications/нелинейность-развитиявысшего-образования-контуры-концепции-и-воз

11. A. Gunn, M. Mintrom. J. High. Educ. Policy Manag., 35 (2). 179 (2013). DOI: https://doi.org/10.1080/1360080X.2013.775926

12. T. Markova, I. Pervukhina, S. Pyankova. Scientific Works of the Free Economic Society of Russia, 211 (3). 559 (2018)

13. D. Marsh, M. Smith. Polit. Stud., 48 (1). 4 (2000). DOI: https://doi.org/10.1111/14679248.00247 